\title{
INTERPRETATION OF VALUES IN THE EPITAPHS ON THE TOMBSTONES OF OLD JEWISH CEMETERY IN BRATISLAVA
}

The aim of the paper is to find the most frequent links and connotations of the notions related to the values of the Jewish religious community in Bratislava before WWII. We understand community as an entity that requires adherence to a set of values, norms, and meanings; religious community is understood as one of the most important and influential constitutive communities in human life. We have therefore decided to process and analyse selected concepts and their closest semantic determinations in the corpus of epitaphs which were found on the tombstones of the Old Jewish Cemetery (already largely destroyed) in Bratislava. The research will be realized via advanced text analysis instruments and new IT tools which are gradually being introduced in wider research of humanities. Based on the research results, we will try to identify the basic values within this community and determine its interpretative traditions.

Keywords: Jewish community, shared values, epitaphs, digital humanities, distant reading

\section{Introduction}

The interactions between Natural Language Processing and Digital Humanities have a major effect on contemporary text analysis. The methods used in humanities (Linguistics, Literary Theory, Literary History, Philosophy, Religion studies etc.) that are used for the text analysis undergo essential transformation caused by the application of digital technologies within all areas of humanities research. The most visible change is caused by digitalisation of text resources, something that has completely changed the design of text archives. The research scale today is, so to speak, thousand times bigger than before. Therefore the methods of research in humanities have changed, too.

This paper aims to use the methods and tools of advanced text analysis in order to analyse the epitaphs on the tombstones of the Old Jewish Cemetery in Bratislava. We intend to demonstrate the way in which it is possible to apply text mining software to the texts of the epitaphs since we suppose that they reflect the basic values of Bratislava Jewish community from $17^{\text {th }}$ to $19^{\text {th }}$ centuries.

\section{Theoretical background of religious communities as constitutive communities of memory}

Religion has always been considered one of the influential sources of moral culture (e. g. Etzioni [1], Coughlin [2], Selznick
[3] and others). It helps people to find the meaning of the world and life, enriches culture, and enables communities to prosper. Moreover, it helps individuals - being the members of the community - to build strong identities. Therefore religion is capable of constituting both the individual as well as the community itself. This is the reason why religious communities as "communities of memory" [4] are considered to be constitutive - they answer the question "Who are we" and constitute the identity of an individual. Religions answer the questions of the transcendent, and they support the virtues of piety leading people to the sources from which they derive their identity and consequently their values and concepts of good.

As a result, for many societies and their social order religion in its moderate form is the main source of moral culture. God is often associated with moral truth, which is transmitted into living traditions, rituals, teachings, and institutions. This point is crucial to the alliance of religious beliefs. The most important principle is the principle of moral equality, which results from the understanding of people as God's children, as beings created in the image of God. This principle can also be justified by non-theological arguments when pointing out the evil which is caused by its non-observance in society (discrimination, privileges resulting from social status, etc.). These are practices that do not correspond with the conviction of the same respect for the people and their dignity. Consequently, religious ideas contribute to the understanding of public morality in society, in particular by

\footnotetext{
* Jarmila Jurova, Marek Debnar

Department of General and Applied Ethics, Faculty of Arts, Constantine the Philosopher University in Nitra, Slovakia

E-mail: jjurova@ukf.sk, mdebnar@ukf.sk
} 
defining and promoting key values such as human dignity and responsibility, humility and self-control, duty towards the family and community, care for future generations, the weak and the sick, and the pursuit of reconciliation [3, p. 62]. And, finally, religion reminds people of their fundamental obligations and duties, hence, it in a sense becomes a conscience of the community.

\section{Jewish community and its values}

Judaism incorporates a range of different values, ideas, and beliefs, which are perceived as God's word of guidance to the way of life. The Jews respect many duties from God which include the essentials of life, based on the Torah and Talmud. The central concept of the Jewish religion is being humble, generous and caring, as written in the Bible: "Do not seek revenge or bear a grudge against anyone among your people, but love your neighbor as yourself. I am the Lord" [5]. It refers to loving yourself and learning to love and accept others the same way. Hence respect and learning to accept differences is the most important element as it proves to God that you are acquiescent and loving.

Morality in Judaism is not minimally observed from deeds but is also a combination of good deeds, thoughts, intentions, attitudes, and doings. The Jews believe that God appointed them to be his chosen people to set an example of holiness and ethical behaviour to the world. Therefore, Jewish life is very much the life of a community, and there are many activities that the Jews must do as a community (e. g. the Jewish prayer book uses "we" and "our" in prayers where some other faiths would use "I" and "mine"). Moreover, the Jews also feel part of a global community with a close bond with Jewish people all over the world. They believe that offering to the poor is a very crucial part of religious life. Synagogues often have charity funds to support those in need or less fortunate. Together with community centres, religious youth groups, and camps, they are commonly known to the Jewish people as their second homes where each individual can have a sense of security and should feel comfortable. Our research will prove that some of these values are also included in the text of epitaphs on the tombstones of the Old Jewish Cemetery in Bratislava.

\section{Old Jewish cemetery in Bratislava}

The remains of the oldest Jewish cemetery in Bratislava, which is the subject of our interest, are now found behind a metal fence that separates it from Chatam Sofer Memorial (1762-1839), the world-renowned rabbi Mosche Schreiber from Frankfurt am Main. The then Jewish community had more than 15,000 members, but in the Holocaust, only 3500 people survived, many of whom later left the city and emigrated $[6, p .6]$.
According to the archive data, the Old Jewish Cemetery in Bratislava began officially to function in 1695 , but the oldest found tombstone was built in 1655 . The last burial took place here in 1847 because a new Orthodox cemetery on Zizkova Street in Bratislava was established a year before. However, the old cemetery, where approximately 6,000 graves were located, was still frequently visited not only by survivors who buried their loved ones here, but it has also become an important pilgrimage place where the believers commemorated the remembrance of the teacher and scholar Rabbi Chatam Sofer as well as other spiritual leaders of the community. Besides the rabbis of the then Jewish community, members of important Bratislava families, such as the family of Oppenheimer, Pressburger, Bettelheim, Pappenheimer, but also ancestors of poet Heinrich Heine or revolutionary Karol Marx, were buried in this cemetery.

During the Holocaust (October 4, 1943), the Old Jewish Cemetery was abolished by the Ministry of Transport and Public Works, which decided to build a tunnel for civil defense needs. Previously, however, Robert Neumann has documented and translated into German all readable texts on the tombstones, which have preserved valuable documents on today's practically unknown Bratislava past. Slovak translation of selected epitaphs was published in 2006 in a book Epitaphs of the Old Cemetery / Epitafy stareho cintorina with the Preface by Peter Salner [6].

\section{Epitaphs on the tombstones}

The sacredness of the burial place is typical for Christianity [7, p. 24] as well as for Judaism. In the course of history, the tombstone (Hebr. הבצמ, matzevah) had various forms, ranging from a simple stela to a tomb. In the Middle Ages, it was customary to write texts about the life of the deceased on the tombstone and to highlight his merits; while in the modern times, the name and the dates of birth and death are curved into the tombstone.

In the Jewish tradition, the tombstone is usually unveiled twelve months after the ceremony (in some communities it is earlier - after seven or thirty days). Should the unveiling ceremony happen on holiday, the placement of the tombstone on the grave must be postponed. In the Ashkenazi communities, there is a tradition of placing a tombstone at the feet of the deceased, in Sephardic communities, the tradition is opposite [8]. Moreover, the Jewish tombstones usually also contain (apart from the basic data mentioned above) references to the good characteristics, typical features, and values of the deceased.

In the ritual area of Judaism, epitaph has been deeply rooted. The inner structure of the text points to its homogeneity with biblical, rabbinic and cabalistic thinking, and in this context of tradition, it provides a narrative about the life and the decease of the buried [9, p. 173]. The romantic poet, William Wordworth, considered epitaph even a separate genre: Epitaphs 
are interpreted as an independent artistic genre the purpose of which is the "restoration of life in the face of death" [10, p. 74] Therefore we suppose that the epitaphs on Jewish tombstones contain the values highly appreciated by the Jewish religious community.

The texts on the tombstones of the members of the Jewish community who were buried in the Old Jewish Cemetery in Bratislava are valuable material that opens the door to the still closed world of Judaism to us. At least in part, they can get to know the thinking, poetics, and values of the faithful Jews, as well as the gradual transformations of the Bratislava Jewry in the two centuries. As a whole, epitaphs contain much information that can be used in the future for deeper sociological or anthropological analyses.

All the tombstones contain a Jewish name (after the introduction of the rules of Joseph II at the end of the 18th century and the official, mostly German, surname) of the deceased and the name of his father. The date of death and burial according to the Jewish calendar must not be missed, but the date of birth is not stated. Frequent is information about the birth, profession and personal characteristics of the deceased. Many texts contain (albeit not very poetic) the expression of the sadness of the survivors. And, naturally, the epitaphs contain many references to the Torah, to a lesser extent to the Talmud.

Our research is based on the corpus of almost 1,000 epitaphs preserved on the tombstones of individuals and families. These epitaphs are from the period between 1708 and 1846. Only a selection of them was published [6] in Slovak, combining the translation from Yiddish, Hebrew, and German. Our paper processes not only published epitaphs but all of those which have been preserved from that period.

Epitaphs illustrate the variety of language as well as the values of Bratislava Jewish community in the $18^{\text {th }}$ and $19^{\text {th }}$ century. Besides basic information about the name, the date of death and date of burial, the analysed epitaphs include other texts of different length. Some of them contain only a short characteristics of the deceased in one sentence, e.g. epitaph on the tombstone 260: "Here lies the respected, virtuous and honourable Mrs. Esterl, wife of Leeb coref. She died and was buried Sunday, 19 Av 5543." / "Tu lezi vazena, cnostna a pocestna pani Esterl, manzelka Leeba corefa. Zomrela a bola pochovana v nedelu 19. ava 5543." [6, p. 56]. Others are richer in content, e.g. epitaph on the tombstone 833: "Here lies a just man, master of his trade, a doctor full of understanding, Mordechai Augenfeld, of blessed memory. Mordechai asked for good for his people. He performed the work of mercy and cured the poor unwell for free. May the Eternal repay him with good. He died and was buried Friday, 9 Tammuz 5589." / "Tu lezi spravodlivy muz ovladajuci svoj odbor, lekar plny pochopenia, Mordechaj Augenfeld blahej pamati. Mordechaj ziadal dobro pre svoj narod. Konal milost a biednych chorych liecil bezplatne. Nech mu to Vecny $k$ dobru pripocita. Zomrel a bol pochovany v piatok 9. tamuza 5589.“ [6, p. 113].

\section{The methodology of the research}

IT tools usable in wider humanities can be divided into several groups according to their functionality. The first are annotation tools that allow you to associate the metadata with the electronic text so you can search for specific elements in texts as well as in comments added by readers. These are tools that can be regarded as a kind of close reading in terms of access to the text. An example of such a tool is the eMargin [11] which allows the user to add comments to individual pieces of electronic text and to create hyperlinks within the text. The tool's features as a whole are a kind of virtual reader's notebook that can be shared with other readers of the same text. However, this tool is currently receding, as the implementation of text metadata (in the case of eMargin for readers' comments) is now part of the construction of corpora and belongs to the second, larger group of tools for building them.

Another group is a modified corpus linguistics tool that covers a set of conversion, statistics, and visualization functions, allowing to perform multiple tasks ranging from searching to various graphical representations of extracted quantitative data. For example, we can mention the Voyant [12] and AntConc [13] tools, which allow the user to create visualizations of their own text corpus (statistics, graphs, table outputs). Because the extraction of text data is primarily based on corpuscles that belong to basic subjects of second-hand reading, we find the most freely available IT tools in this group. For the needs of text analysis in this case, it is necessary to have localizations of these tools and digital versions of the analyzed texts. Especially valuable on instruments of corpus linguistics is that, in addition to simple statistical data (frequency of words, etc.), the user can also get more precise data from the text: groups of semantically related terms or phrases. These form the basis of the third group of tools, which are focused on even a more precise text mining.

The development of these most advanced tools takes place in various DH groups dealing with text analysis. One of the examples is the Computational Stylistic Group [14] which - using the quantitative linguistics method - can identify the strategy of the text up to the author's idiolect. Stylo R, developed by the Computational Stylistic Group, is not just a text extraction tool but also a programming language available on the group's pages along with the freely accessible corpora of literary texts such as Shakespeare's works, classical British novels, and so on.

In our research, we used both tools mentioned in the second group. Voyant was used to visualize the results via cirrus, collocates graphs, and trends. Cirrus is a word cloud that visualizes the top frequency words of a corpus or document, while the word cloud positions the words such that the terms that occur the most frequently are positioned centrally and are sized the largest (see Figure 1). The collocate graph represents keywords and terms that occur in close proximity as a force directed network graph (see Figure 2 and Figure 3). Trends is a line graph depicting the 


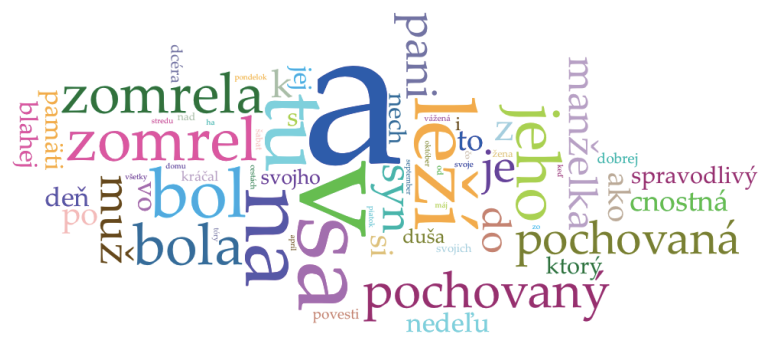

Figure 1 Cirrus of the most frequented tokens

See Annex for English equivalents of the tokens and collocates

distribution of a word's occurrence across a corpus or document (see Figure 6 and Figure 8). AntConc was used for a deeper text analysis, searching for word frequencies and collocations (Figure 4, Figure 5, Figure 7).

\section{Research results and interpretation}

The total corpus extent is 42,154 tokens, (while "token" refers to all the text units / parts of speech, including conjunctions, prepositions, etc.), which corresponds to 908 epitaphs in Yiddish and other 30 epitaphs in Hebrew.

Figure 1 illustrates the most frequent words found in the epitaphs we analysed. The first 10 words in raw (total count) frequency are: died / zomrel/a - 774 (408 men, 366 women); (here) lies... / tu lezi... - 641; buried / pochovany/a - 605 (314 men, 291 women); son syn - 275; man / muz - 264; wife / manzelka - 253; virtuous (woman) / cnostna - 196; day (Sunday) / den (nedela) 182; of blessed memory / blahej pamati - 182; just / spravodlivy - 172.

The most common ethical notions identified in our research are virtuous / cnostna and just (man) - spravodlivy, while the first one refers mostly to women (196) and the second to men (172). Figure 2 and Figure 3 (collocates graphs) illustrate the further difference in the occurrence of particular values depending on the gender of the deceased. Justice / spravodlivost as a value occurs only 37 times and it refers to women, and it is always accompanied with another adjective describing characteristics of a woman: virtuous / cnostna and/or just / spravodliva and/ or venerable / ctihodna etc. Adjective virtuous / cnostny related to a man occurs only once (epitaph on the tombstone 653: "Moshe was virtuous and led many Israelites to virtue." / "Mose bol cnostny a mnohych Izraelitov viedol $k$ cnosti."). In the epitaphs, virtue / cnost as a noun occurs only 6 times, while in 4 cases it is associated with women and only in 2 cases it was mentioned in the epitaph on the tombstone of a man (epitaph on the tombstone 754/1: "He sowed virtue in his life and reaped a two-fold reward in death, a two-fold glory." / "Sial cnost v zivote a po smrti zozal dvojnasobnu odmenu, dvojnasobnu poctu."; and epitaph on the tombstone 59: "Virtue glows from the East." / "Z vychodu ziari cnost.").

Another value frequently occurring in the epitaphs is piety / zboznost. It occurs 116 times (66 times in connection with men,

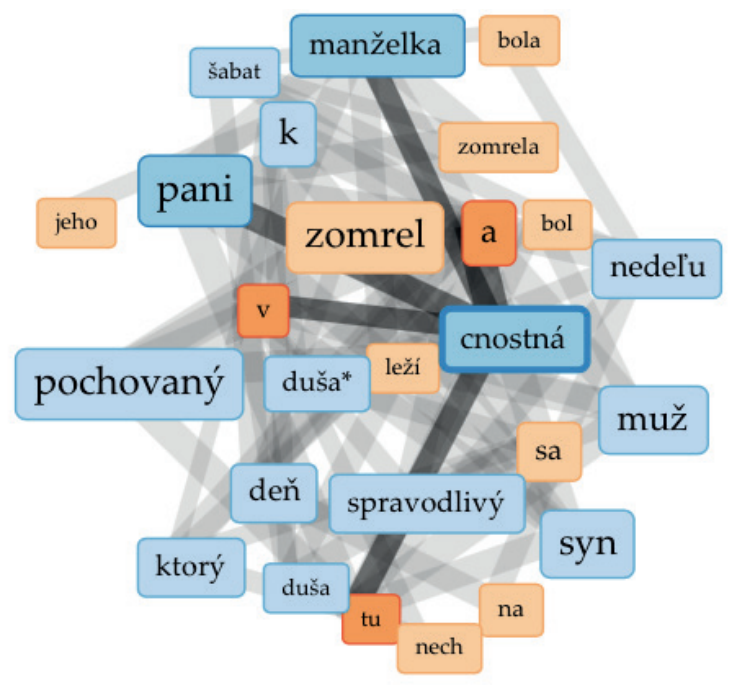

Figure 2 Collocates graph of virtuous / cnostna (woman) See Annex for English equivalents of the tokens and collocates

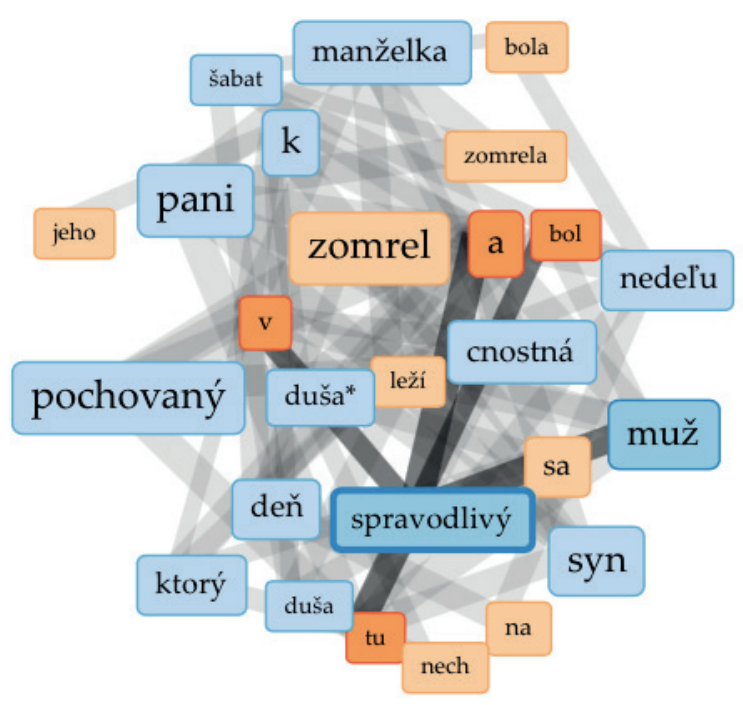

Figure 3 Collocates graph of just (man) / spravodlivy See Annex for English equivalents of the tokens and collocates

and 50 times with women). The collocations presented in Figure 4 and Figure 5 give the evidence about the occurrence of this value together with the above-presented values: notions just / spravodlivy (related to men) and virtuous / cnostna (related to women).

Figure 6 and Figure 7 illustrate another most frequent collocation referring to the value of reputation. Good reputation / dobra povest occurs 131 times in the epitaphs and relates to men as well as to women.

Besides the ethical and moral values presented in the previous graphs, the occurrence of the notion of soul, which has been found on the analysed epitaphs, is also interesting. This notion mostly occurs in connection with the phrase which we can still find on tombstones in its apocryphal form [10]: "Tihje nafso 


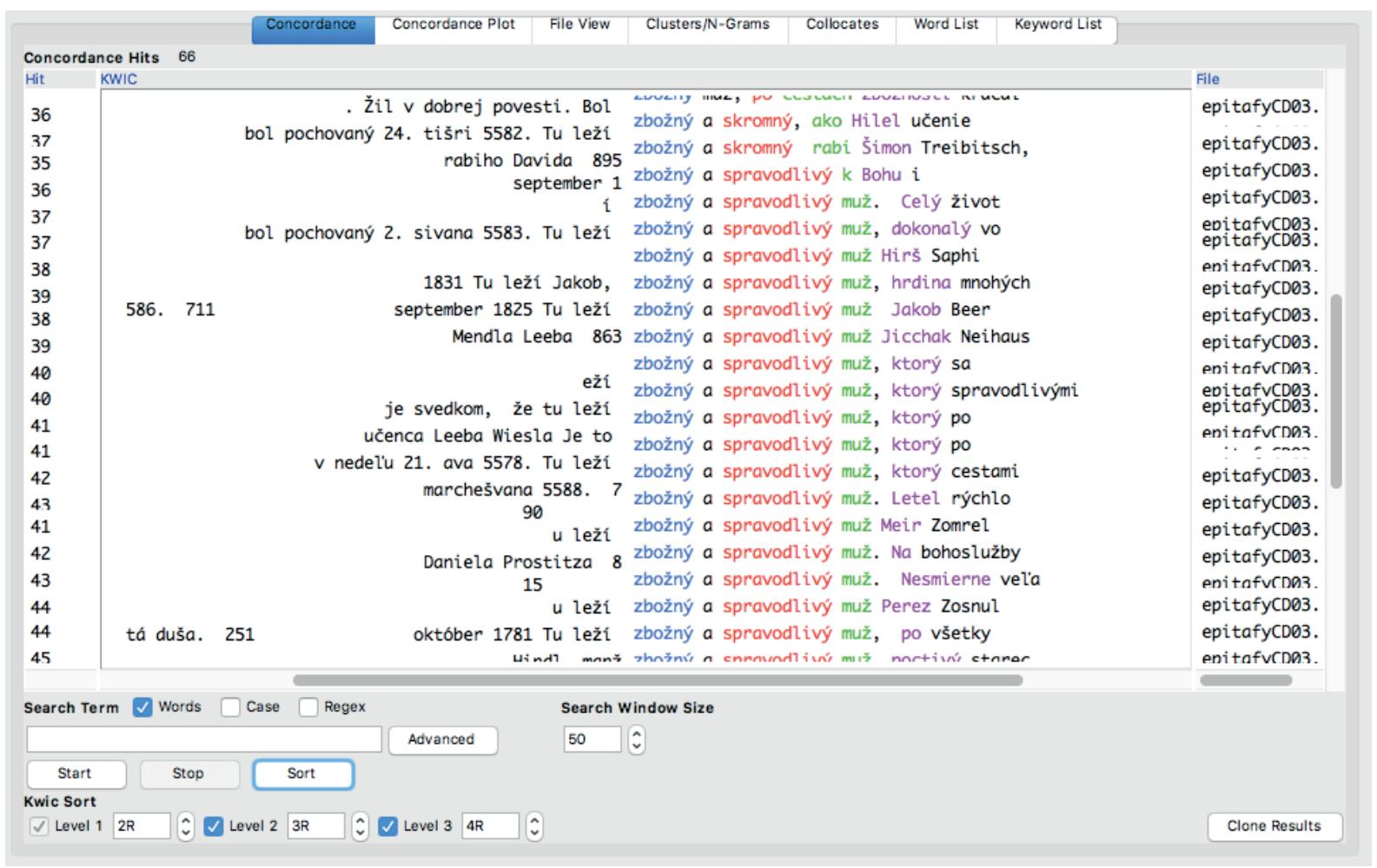

Figure 4 Piety (of men) / zboznost (muzov) See Annex for English equivalents of the tokens and collocates

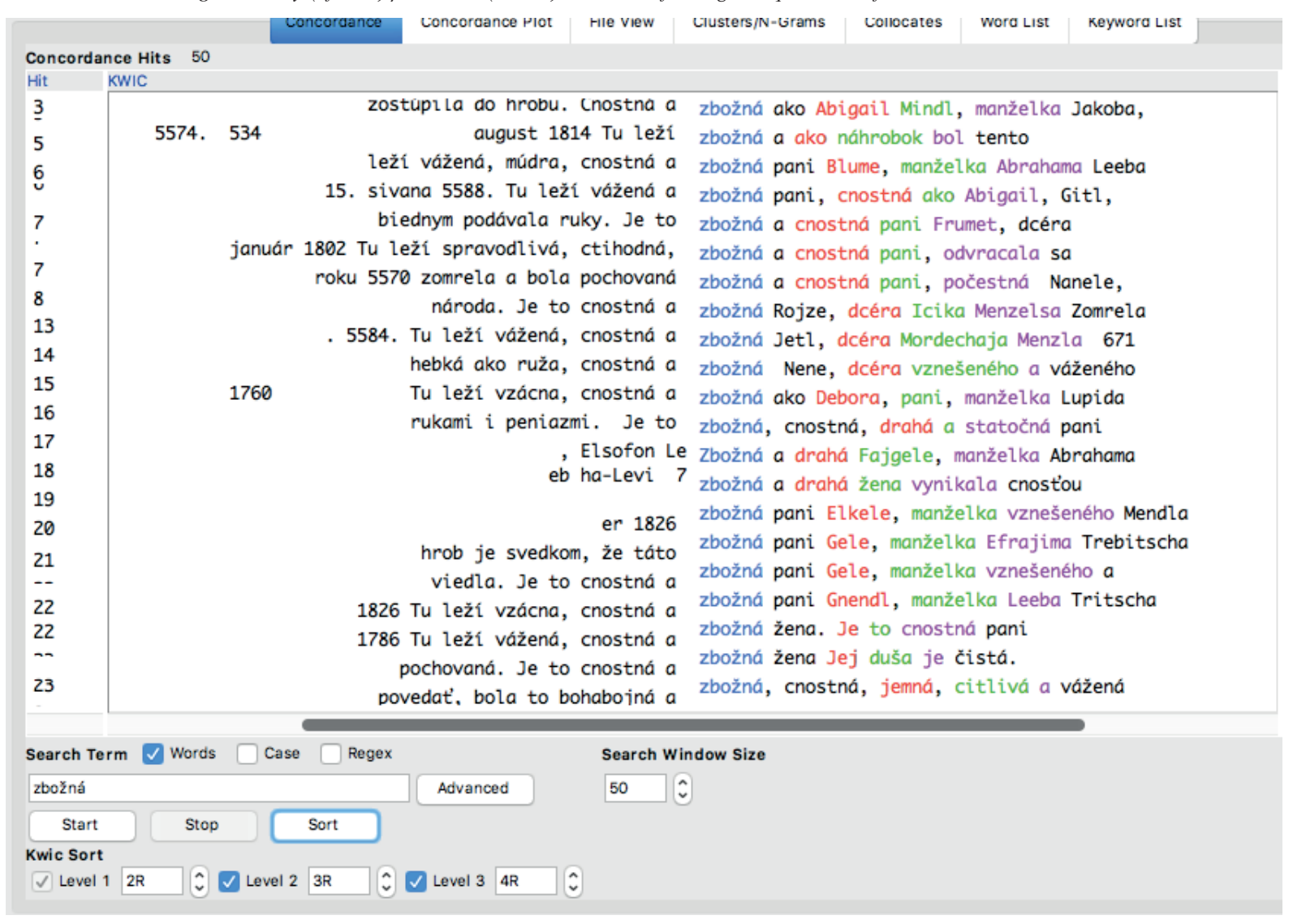

Figure 5 Piety (of women) / zboznost (zien) See Annex for English equivalents of the tokens and collocates 


\section{KonNllkCle}

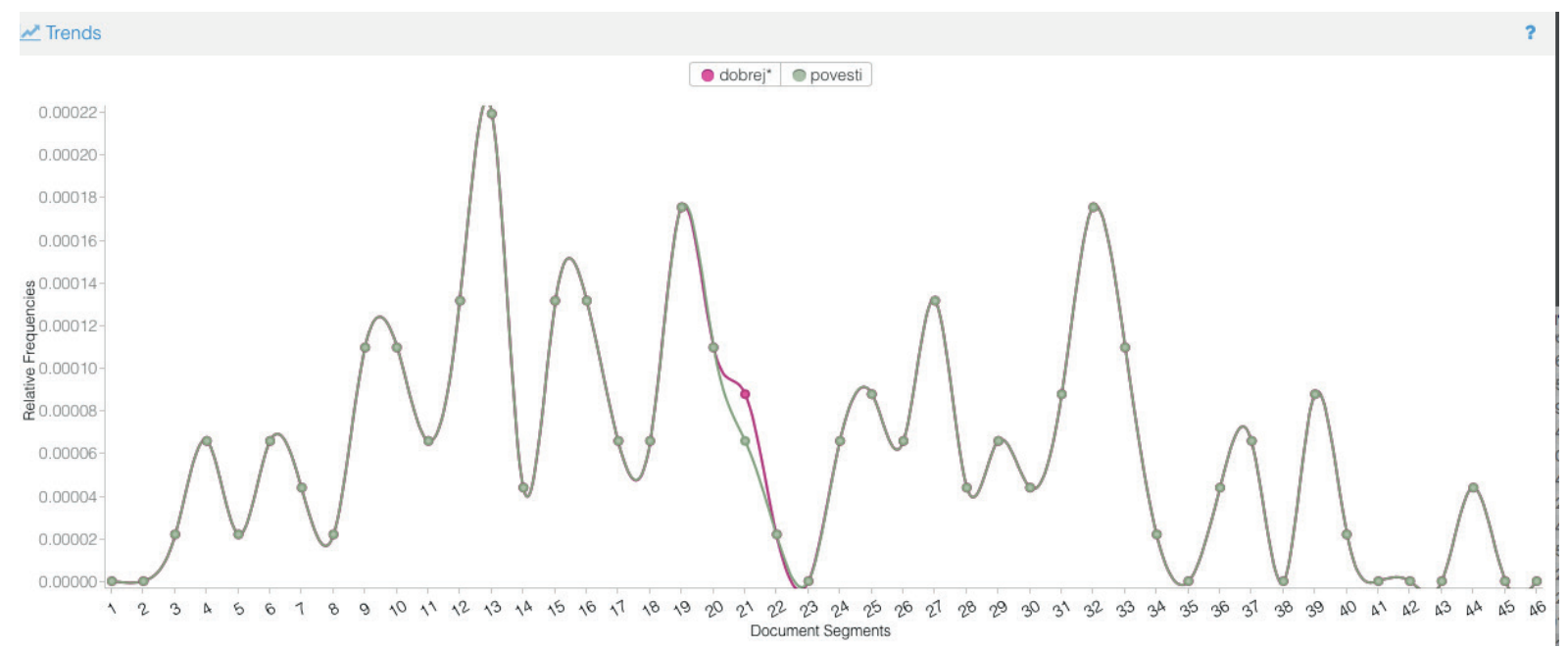

Figure 6 The occurrence of notions good + reputation / dobra + povest

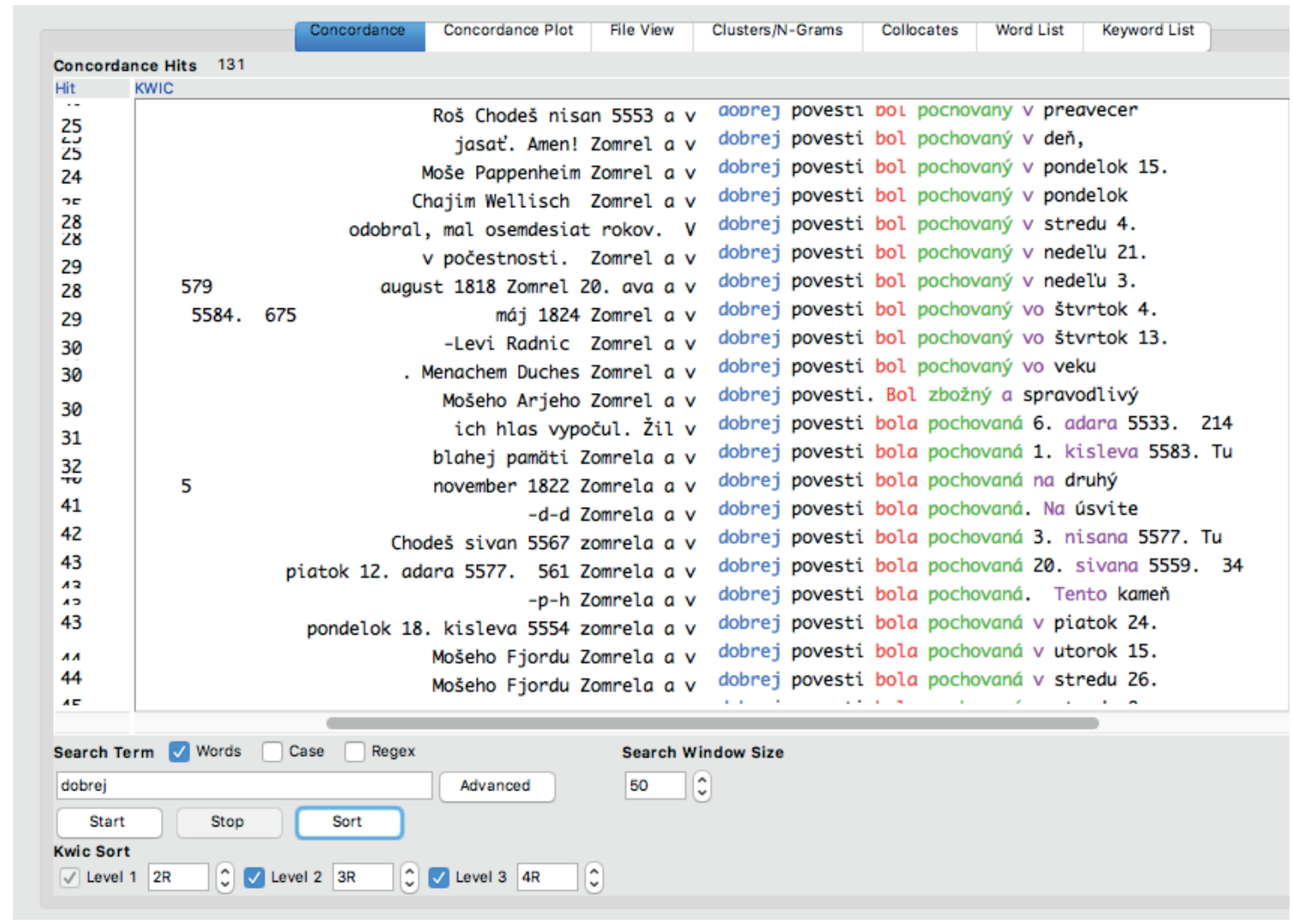

Figure 7 Good reputation / dobra povest

See Annex for English equivalents of the tokens and collocates

(nefes) crura bi-cror ha-chajim." / "May his/her soul be bound in the bond of everlasting life". However, the notion of the soul also occurs in other meanings in Judaism [15, pp. 116 - 119]. One of them refers to the soul as a character (nesama), such as in the phrase: pure soul / cista dusa (Figure 8), which is found mostly on the tombstones of rabbis and benefactors of the community (e. g. epitaph on the tombstone 95: "Until his old age, he came to house of prayer every morning and every evening. He served the Lord with awe and joy. He acted bravely. He was a famous speaker, a faithful shepherd full of knowledge, wisdom, and understanding. His soul soared in holiness and purity." / "Az do svojho stareckeho veku chodil rano i vecer do domu modlitieb. Sluzil Vecnemu s baznou a chvel sa radostou. Pocinal si statocne. Bol slavny recnik, verny pastier 


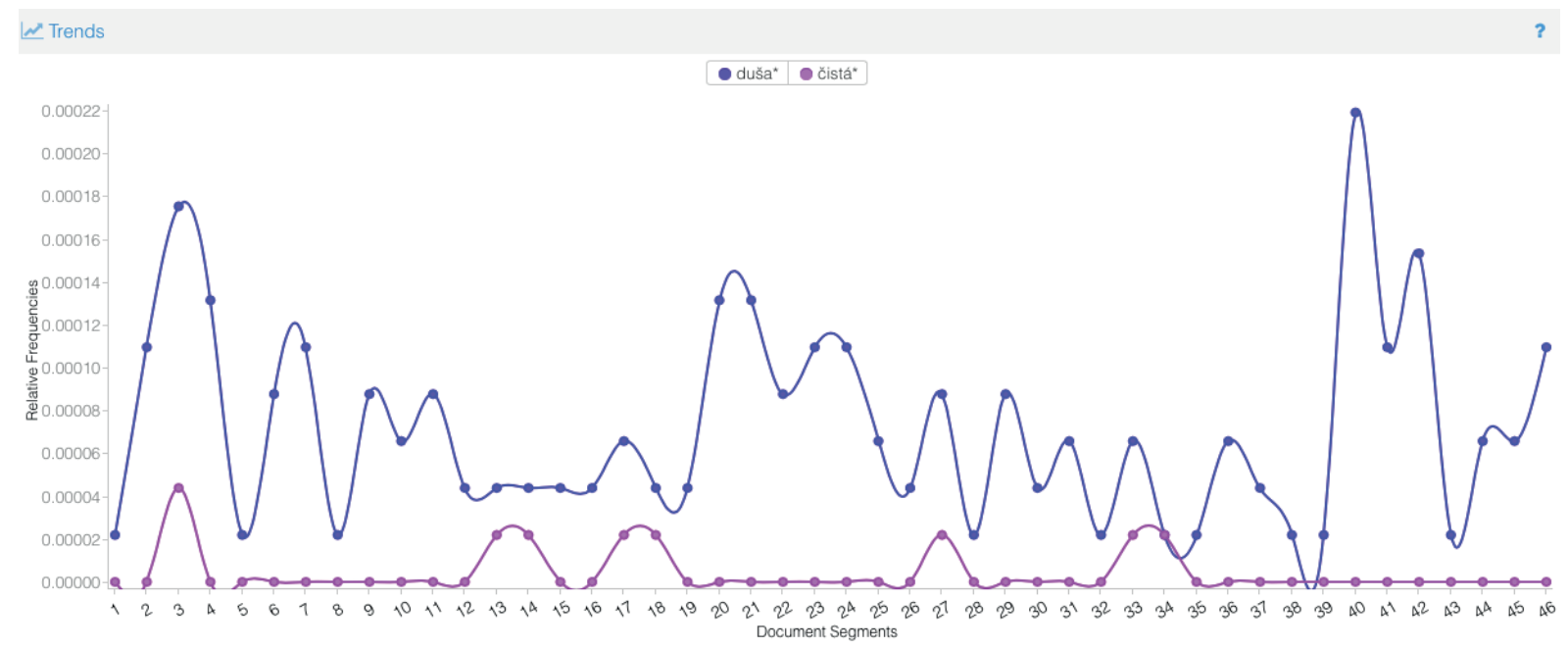

Figure 8 The occurrence of notions pure + soul / cista $+d u s a$

plny mudrosti, rozumu a pochopenia. Jeho dusa vzlietla $\mathrm{v}$ svatosti a v cistote.").

In addition, many other ethical notions and interesting collocations can be identified via the text mining method which we used in our research. To mention some of them, the collocation full of understanding / plny pochopenia, which can be interpreted as a value of benefaction, occurs in the analysed epitaphs: e. g. a doctor who "cured the poor unwell for free" (tombstone 833); or a wealthy man who supported students of the Torah: "Here lies a noble person, who, until the eightieth year of his age, before his vision blurred, devoted himself to study of Torah. He read and learned and left the world with good reputation and great knowledge. Now his luster has passed. He is a scholar, the honourable elder Saul, of blessed memory 5504." / "Tu lezi vzacny clovek, ktory az do osemdesiateho roku svojho zivota, kym sa mu nezakalil zrak, venoval cas studiu Tory. Cital a ucil sa a odisiel zo sveta s dobrou povestou a velkou mudrostou. Teraz sa pominul jeho lesk. Je to ucenec, dostojny kmet Savl blahej pamati 5504." (tombstone 66).

Using the IT tools of textual analysis in the process of examining the ethical and moral values of the Jewish community that once lived in Bratislava, we have, on the basis of a conceptual map and frequency charts, revealed not only the most favored values but also the context in which this community expressed them. By doing so, we have successfully demonstrated how to use the potential of DH (digital humanities) in ethical research, and, at the same time, how important it is to convert cultural monuments into digital form, which can be further processed by IT tools. The digital processing of these monuments is an important starting point for follow-up research, including textual analysis, visualization, etc. A quantitative approach can reveal not only the most important values but also how certain values are expressed and acquired by the community.

\section{Conclusion}

We believe that the new approach to the research of humanities presented in this paper gives satisfactory evidence of the fact that the new IT tools and advanced text analysis instruments can be successfully applied in the field of humanities. In this paper - in order to identify the basic values of Bratislava Jewish community of $17^{\text {th }}-19^{\text {th }}$ centuries - we demonstrated its application to the analysis of the epitaphs on the tombstones of Old Jewish Cemetery in Bratislava. To conclude, these tools give human scientists the ability to identify key concepts and connotations quickly and efficiently via text mining instruments, without the close reading of primary sources in the first phase of their research. Obviously, this approach is helpful, but not sufficient in the field of humanities. It can change or redirect the interpretation in the first phase, but, subsequently, it must be necessarily followed by a deeper analysis and interpretation of the identified data.

\section{Acknowledgment}

The text is a partial outcome of national project APVV-160116: Studium byzantskeho hodnotoveho systemu a jeho reflexie $\mathrm{v}$ slovanskom kulturnom prostredi (Study of Byzantine Value System and its Reflection in Slavic Cultural Environment). 


\section{kOMNIIKCCle}

\section{References}

[1] ETZIONI, A.: Religion and Social Order. Policy Review, April - May(148), 59-67, 2008.

[2] COUGHLIN, R.: Does Socioeconomic Inequality Undermine Community? Implications for Communitarian Theory. ETZIONI, A., VOLMERT, A., ROTHSCHILD, E. (Eds.): The Communitarian Reader. Beyond the Essentials. Rowman \& Littlefield Publishers, Inc., Lanham - Boulder - New York - Toronto - Oxford, 117-128, 2004.

[3] SELZNICK, PH.: On a Communitarian Faith. ETZIONI, A., VOLMERT, A., ROTHSCHILD, E. (Eds.): The Communitarian Reader. Beyond the Essentials. Rowman \& Littlefield Publishers, Inc., Lanham - Boulder - New York - Toronto - Oxford, 61 - 68, 2004.

[4] BELL, D.: Communitarianism and its Critics. Clarendon Press, Oxford, 1993.

[5] The Holy Bible: Leviticus 19:18.

[6] ZVONCEKOVA-HAASOVA, D. (Ed.): Epitaphs of the Old Cemetery/Epitafy stareho cintorina (in Slovak). Chajim, Edicia Zidovskej Literatury pri UZ ZNO, Bratislava, 2006.

[7] See Christian tradition of burying in e. g. GOGOVA, S.: Burying of Children in Vessels in Krasno Church Cemetery in Historical Context/Pohreby deti v nadobach na kostolnom cintorine v Krasne v historickom kontexte (in Slovak). Kontexty Kultury a Turizmu, 6(2), 24-26, 2013.

[8] NEWMAN, J., SIVAN, G.: Judaism from A to Z. (Judaica; vol. 1.)/Judaismus od A do Z. (Judaica; zv. 1.) (in Czech). Sefer, Praha, 1992.

[9] KUSANOVA-WIECHA, K.: Text Analysis of the Epitaphs of Old Jewish Cemetery in Bratislava/Textova analyza epitafov zo stareho zidovskeho cintorina v Bratislave (in Slovak). BOTIK, J. (Ed.): Obycajove tradicie pri umrti a pochovavani na Slovensku s osobitnym zretelom na etnicku a konfesionalnu mnohotvarnost. Slovenske narodne muzeum - Historicke muzeum v Bratislave, Bratislava, 173 - 184, 2001

[10] DE MAN, P.: The Retoric of Romanticism. Columbia University Press, New York, 1984.

[11] Online. Available: http://emargin.bcu.ac.uk.

[12] Online. Available: https://voyant-tools.org/.

[13] Online. Available: http://www.laurenceanthony.net/.

[14] Online. Available: https://sites.google.com/site/computationalstylistics/.

[15] For complete understanding of soul in Judaism see COHEN, A.: Talmud (for Everybody)/Talmud (pre kazdeho) (in Slovak). Sefer and European Jewish Publication Society, Praha, 2006.

\section{Annex}

English equivalents of the tokens and collocates used in Figures:

Figures 1 - 3 (in alphabetical order SK - ENG):

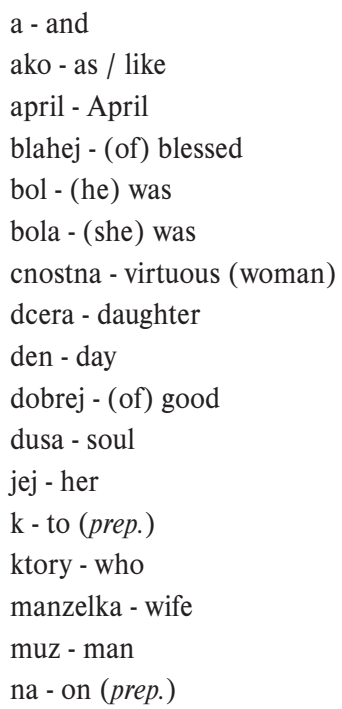

$$
\begin{aligned}
& \text { nad - over (prep.) } \\
& \text { nedela/u - Sunday } \\
& \text { nech - let (it) } \\
& \text { od - from (prep.) } \\
& \text { oktober - October } \\
& \text { pamati - (of) memory } \\
& \text { pani - lady } \\
& \text { piatok - Friday } \\
& \text { po - after } \\
& \text { pochovany/a - buried } \\
& \text { pondelok - Monday } \\
& \text { s - with (prep.) } \\
& \text { sa - reflexive pron. } \\
& \text { sabat - Sabbath } \\
& \text { september - September } \\
& \text { si - reflexive pron. } \\
& \text { skromny - modest (man) }
\end{aligned}
$$


spravodliva - just (woman)

spravodlivost - justice

spravodlivy - just (man)

streda - Wednesday

svojich / svoje / svojho - (of) his / her

syn - son

Figure 4 (SK - ENG):

zbozny a skromny ako Hilel - pious and modest as Hilel

zbozny a skromny rabi Simon - pious and modest rabbi Simon

zbozny a spravodlivy k Bohu - pious and just to God

zbozny a spravodlivy muz - pious and just man

zbozny a spravodlivy muz, dokonaly - pious and just man, perfect

zbozny a spravodlivy muz Hirs - pious and just man Hirs

zbozny a spravodlivy muz, hrdina - pious and just man, hero

zbozny a spravodlivy muz Jakob - pious and just man Jakob

Figure 5 (SK - ENG):

zbozna ako Abigail Mindl, manzelka Jakoba - pious like Abigail Mindl, wife of Jakob

zbozna a ako nahrobok bol tento - pious and like a tombstone was this

zbozna pani Blume, manzelka Abrahama - pious lady Blume, wife of Abraham

zbozna pani, cnostna ako Abigail - pious lady, virtuous like Abigail zbozna a cnostna pani Frumet - pious and virtous lady Frumet

zbozna a cnostna pani, odvracala sa - pious and virtuous lady, turning away from

zbozna a cnostna pani, pocestna - pious and virtuous lady, honourable

zbozna Rojze, dcera Icika Menzelsa - pious Rojze, daughter of Icik Menzels

zbozna Jetl, dcera Mordechaja Menzla - pious Jetl, daughter of Mordechaj Menzl

zbozna Nene, dcera vzneseneho a - pious Nene, daughter of a noble and

Figure 7 (SK - ENG):

$\mathrm{v}$ dobrej povesti bol pochovany - in a good reputation he was buried

$\mathrm{v}$ dobrej povesti. Bol zbozny a - in a good reputation. He was pious and

\author{
to - it \\ vo - in (prep.) \\ vsetky - all \\ $\mathrm{z}$ - from (prep.) \\ zomrel / zosnul - (he) died \\ zomrela - (she) died
}

zbozny a spravodlivy muz Jicchak - pious and just man Jicchak zbozny a spravodlivy muz, ktory - pious and just man who zbozny a spravodlivy muz. Letel - pious and just man Letel zbozny a spravodlivy muz Meir - pious and just man Mejr zbozny a spravodlivy muz. Na bohosluzby - pious and just man. On (church) service

zbozny a spravodlivy muz. Nesmierne vela - pious and just man Extremely much / many

zbozny a spravodlivy muz Perez - pious and just man Perez

zbozna ako Debora, pani, manzelka - pious like Debora, lady, wife zbozna, cnostna, draha a statocna - pious, virtuous, and brave zbozna a draha Fajgele, manzelka - pious and dear Fajgele, wife zbozna a draha zena, vynikala - pious and dear woman, distinguished

zbozna pani Elkele, manzelka vzneseneho - pious lady Elkele, wife of a noble

zbozna pani Gele, manzelka Efrajima - pious lady Gele, wife of Efrajim

zbozna pani Gele, manzelka vzneseneho - pious lady Gele, wife of a noble

zbozna pani Gnendl, manzelka Leeba - pious lady Gnendl, wife of Leeb

zbozna zena. Je to cnostna pani - pious woman, She is a virtuous lady

zbozna zena. Jej dusa je - pious woman. Her soul is

zbozna, cnostna, jemna, citliva a - pious, virtuous, gentle and

$\mathrm{v}$ dobrej povesti bola pochovana - in a good reputation she was buried 